\title{
The Virtue Approach to Moral Education: Some Conceptual Clarifications
}

\author{
JAN W. STEUTEL
}

There is a lot of talking and writing on virtues and education nowadays. In spite of this, a clear and convincing account of the defining characteristics of the virtue approach to moral education is still lacking. This paper suggests and discusses three different definitions of such an approach. With reference to each definition it is examined whether the virtue approach can be distinguished from other main perspectives on moral education, in particular from the so-called cognitive-developmental approach (including the just community approach). It is argued that only the definition that refers to an ethics of virtue will have the required differentiating capacity. Consequently, only on the basis of this definition can the virtue approach be regarded as a qualitatively new development in research on moral education.

\section{INTRODUCTION AND FORMULATION OF THE PROBLEM}

In 1988, to be precise, a new edition of Roger Straughan's Can We Teach Children to be Good? was published. In the second chapter of this book there is a clear and neatly arranged overview of the main approaches to moral education, including value transmission, values clarification and the cognitive-developmental approach. It is striking, however, that an important approach seems to be lacking, or at least is not explicitly mentioned, namely the so-called virtue approach to moral education. This omission is remarkable, for even someone who followed developments in research on moral education from a distance could not fail to notice that since the early 1980s an ever-increasing number of essays appeared in which words like 'virtue', 'virtuous' and 'character' figure prominently. Some authors even speak of a new trend, a shift towards an essentially different perspective on moral education, although they acknowledge that this new approach goes back to character education practices around the turn of the century and, much longer ago, to the ethical views of the ancients ( $c f$. Atherton, 1988; Nash, 1988; Nucci, 1989). 
But in spite of a lot of recent thinking and writing on virtues and moral education there still is no elaborated and systematic account of the defining characteristics of the virtue approach, nor of the essential differences between such an approach and other conceptions of moral education. It is true that champions of the modern character-education movement have given descriptions of the main characteristics or central principles of character education. Mostly, however, these accounts are without philosophical depth and often mutually incompatible. More importantly, the descriptions are nearly always indecisive with regard to the logical status of the indicated features or principles: are they considered to be defining characteristics (part of the concept of character education, so to speak) or just regarded as accompanying ones (only typical of a certain conception of character education)? Moreover, though advocates of character education often speak about virtues and virtuousness, it is unclear whether or not they would regard 'character education approach' and 'virtue approach' as interchangeable expressions.

Yet a convincing and well-founded analysis of the defining characteristics of a virtue approach is a prerequisite for tackling more important problems, in particular questions regarding its relative value or merit. For if we do not know exactly what a virtue approach is, how could we evaluate its philosophical basis in terms of criteria of theoretical adequacy, like consistency, coherence, unity and economy? And if the logical distinctions between the virtue approach and other perspectives on moral education are unclear to us, how could we compare and assess its practical implications?

In this paper I shall try to obtain the desired systematic understanding by distinguishing three plausible definitions of the virtue approach. In publications on virtues and moral education the expression 'virtue approach' is normally used in a rather vague and ambiguous way. And because the definitions that will be proposed establish precise and distinct meanings, they can be regarded as constructions. They are not, however, arbitrary constructions, since they still are based on and refer to those implicit and often rudimentary meanings in relevant publications. ${ }^{1}$ When discussing these definitions, I will observe a certain logical order: first the broadest definition is proposed, after which subsequently more restrictive definitions are introduced by adding certain defining characteristics. In other words, the order runs from the definition with the smallest content and the largest extension to the definition with the largest content and the smallest extension.

Moreover, with reference to each definition I shall examine whether or not it applies to the cognitive-developmental approach of Kohlberg and his colleagues. This comparative analysis is not only meant as an additional illustration of the definitions proposed. Primarily I want to make clear whether the virtue approach, given the successive definitions, can indeed be distinguished from other approaches and thus possibly can be regarded as representing a qualitatively new development in research on moral education. For decades the views of Kohlberg were 
trend-setting and predominant (and in certain respects they still are). So if the virtue approach is really something new and different, a plausible definition has to be proposed that at least is not applicable to the cognitive-developmental theory.

\section{A FIRST DEFINITION: TRAITS OF CHARACTER AS AIMS OF MORAL EDUCATION}

In education, including moral education, all sorts of aims are pursued, from skills and capacities to attitudes and commitments, from knowledge and understanding to manners and habits. With reference to William Frankena (1973a, p.20) we could call all these aims of education dispositions. But then we should realise that we use the word 'disposition' in a rather broad and technical sense, roughly as a synonym of 'state of mind' or 'quality of mind'.

If we use the term in this way, virtues are by definition dispositions that we value somehow positively. And vices are then obviously dispositions that we value in some way negatively. However, not all dispositions to which we attach positive value are virtues. Take, for example, linguistic skill, mathematical perception, vitality, wittiness, joy in life and intelligence. Normally we admire these qualities or value them positively in some other way. Yet calling them virtues would not be appropriate. Nor are all dispositions to which we assign negative value vices. Think, for instance, of clumsiness, emotional instability, bad memory, muddle-headedness or musical insensitivity. In general we deplore these qualities or value them negatively in another way. But calling these dispositions vices would be counter-intuitive.

Apparently virtues and vices constitute a particular subclass of dispositions. A subclass that is often mentioned in this connection is the group of character traits. And indeed, not only do all virtues and vices appear to be traits of character, it seems also possible to regard all traits of character as virtues or vices. If we describe someone's character in positive terms, for example by saying that he is fair, honest, loyal, helpful and courageous, we are ipso facto referring to certain virtues. And if we give a negative description of someone's character, for example by calling him biased, unreliable, mendacious, cowardly or impatient, we are necessarily enumerating particular vices ( $c f$. Dent, 1984, pp. 9-10).

Now according to a first definition that I want to discuss, an approach to moral education is a virtue approach if, and only if, fostering certain traits of character is advocated or recommended. Because education is by definition an aim-oriented activity, in every approach to moral education certain dispositions are considered educational aims. And if traits of character or virtues are among these dispositions, the approach at issue is rightly regarded as a virtue approach.

This first definition is rather broad. If we adopt it, it can easily be demonstrated that Straughan (1988) discusses conceptions of moral 
education that can be regarded as virtue approaches. Take, for example, the approach that is known as value transmission. According to this time-honoured view, moral education consists in inculcating certain values. As examples of often-recommended values Straughan mentions truthfulness, perseverance, patience and respect for others (pp. 13-14). And what else could transmitting such values be but fostering the corresponding virtues? Even the approach that explicitly rejects inculcating values, so-called 'values clarification', argues implicitly in favour of cultivating certain virtues. For example, the pupil is stimulated to respect and to take seriously divergent conceptions of the good, which can be explained in terms of fostering the virtue of tolerance. Moreover, the pupil is encouraged to bridge a possible gap between his conception of the good and his behaviour, which implies that value is attached to the development of such virtues as perseverance, self-control and tenacity. Perhaps it is even possible to defend the thesis that according to the first definition all well-known approaches to moral education are virtue approaches. Which traits of character are considered to be virtues or aims of education can vary from approach to approach. But it is a common characteristic of all main approaches that fostering certain character traits is advocated.

But is this also true of Kohlberg's cognitive-developmental approach? Was not he the one who dismissed the virtue approach by calling it disparagingly 'the bag of virtues approach'? In order to find an appropriate answer to these questions it is important to make a distinction between two phases in the development of Kohlberg's research on moral education. Characteristic of the first phase is that only one aim of moral education is acknowledged and defended, namely, stimulating the stage-by-stage development of the structure of moral reasoning. In the second phase, which begins roughly in the middle of the 1970s, Kohlberg admits that imparting moral content is an important aim of moral education as well. In contrast with the first phase, the educator is no longer exclusively regarded as a 'Socratic facilitator of structural development', but also as a 'socializer teaching value content and behavior' (Kohlberg, 1978, p. 84).

If we observe the first definition, the theory that is typical of Kohlberg's second phase is a clear example of a virtue approach. As is well-known, in that phase Kohlberg and his colleagues developed the socalled 'just community approach'. This view on moral education is an attempt to integrate the theory of the development of structure with a theory about the socialization of content. And this moral content is often explained in terms of virtues. Positive traits that are connected with 'a sense of community', like trust, caring, collective responsibility, a spirit of discipline and democratic participation, are labelled as 'master virtues' and function as central aims of moral education (e.g. Power, Higgins and Kohlberg, 1989). However, it is highly debatable whether Kohlberg's early theory can be called a virtue approach too. In particular during the first phase he has strongly criticised 'the character education approach', in which moral education is reduced to fostering 'a 
bag of virtues'. And time and again he contrasted this view with his own conception, according to which structural development of moral judgement is the only educational aim.

In spite of this, there are various ways of demonstrating that even in the first phase Kohlberg's theory is in fact a virtue approach. One of these ways is the following. Kohlberg has repeatedly discussed the relation between moral judgement and moral behaviour. Referring to certain research results he maintains 'that advance in moral judgment seems to correlate with more mature moral action' (Kohlberg, 1971, pp. 82-83). There is, for example, some evidence that post-conventional subjects cheat much less under certain circumstances than conventional subjects. But even if moral judgement is the most important or influential factor in moral behaviour, it is certainly not the only one. There is a gap between judgement and action, even at the postconventional level, and other factors are needed to bridge that gap. One of these factors, says Kohlberg, is ego strength (e.g. Kohlberg, 1971, pp. 79, 82-84; 1976, pp. 180-181). This technical, theoretical term refers among other things to a group of dispositions that is usually called 'willpower'. And will-power is not only itself regarded as a virtue, it is also a factor that is composed of virtues, including self-control, perseverance, patience and temperance ( $c f$. Steutel, 1992, Ch. 2). So we see that during his first phase Kohlberg attaches importance to the development of virtues too. Even though he does not use the word, the so-called virtues of will-power are considered to be necessary for bridging the gap between moral judgement and moral behaviour. Therefore his theory is, given our first definition, an example of a virtue approach.

\section{A SECOND DEFINITION: TRAITS OF CHARACTER ARE THE ONLY AIMS OF MORAL EDUCATION}

The question could be raised what the value of our first definition is. If according to this definition all well-known perspectives on moral education are in fact virtue approaches, including Kohlberg's theory in its first phase, the definition lacks any differentiating capacity. Consequently it will be impossible to discern any really new development in research on moral education on this basis. But is this a problem? Even if the definition itself does not discriminate, it does show us an interesting way to make a distinction between approaches, namely on the basis of different traits of character that are considered to be aims of education. Anyhow, if we are interested in a definition that distinguishes the virtue approach from other approaches, we will have to add defining conditions that really function as differentia specifica. Which conditions could that be?

The fact that certain traits of character are regarded as aims of education is, according to the first definition, both necessary and sufficient for calling a conception of moral education a virtue approach. We could make this definition more tight by laying down that the term 'virtue approach' is applicable if, and only if, exclusively traits of 
character and their constitutive components are considered as aims of moral education. According to the first definition, the fact that only one of the educational aims is a character trait is already sufficient for speaking of a virtue approach. However, now all dispositions that are regarded as aims of moral education have to be traits of character (or at least have to be considered explicitly as central components of character traits). And that is an additional requirement of no mean importance. For if we, according to this second definition, advocate a virtue approach, we are not only regarding certain traits of character as educational aims but we also claim that beyond these dispositions there is nothing worthwhile to strive for in moral education.

In my recent Deugden en morele opvoeding (Moral Education and the Virtues) (Steutel, 1992) I defended a conception of moral education that, given the second definition, can be regarded as a virtue approach: all aims of moral education are explained in terms of (sub-dispositions of) virtues. When I was writing this study, I assumed that within the wellknown approaches to moral education (with the exception of the character-education approach) aims are advocated that are clearly not traits of character (nor conceived as essential components of such traits). And I was thinking in particular of Kohlberg's theory. But is this correct? Or is, according to our second definition, even the view of Kohlberg actually a virtue approach?

To begin with, let us look at Kohlberg's ideas of his first phase. Characteristic of this phase is that only one aim of moral education is acknowledged, namely the development of the form or structure of moral reasoning. This stage-by-stage development should lead to a postconventional structure of moral reasoning. Now it is striking that in several of his publications of his first phase Kohlberg maintains that a person who judges and acts in accordance with such a structure actually is the bearer of the virtue of justice (e.g. Kohlberg, 1970; 1971, pp. 8081). Consequently, in his view the aim of moral education is not composed of a 'bag of virtues', as is the case in the character education approach, but consists in the end only in one virtue, the complex and abstract virtue of justice. And given our second definition, that would turn his theory into a virtue approach, since next to this virtue no other dispositions are acknowledged as aims of education. ${ }^{2}$

One could object that within a genuine virtue approach a number of traits of character are always regarded as aims of education, and that, therefore, it is not by coincidence that our second definition is phrased in the plural. But even if we consider this objection tenable, Kohlberg's theory of his first phase still remains a virtue approach. For the virtue of justice, as explained by Kohlberg, implies a number of other virtues, including the so-called intellectual virtues like open-mindedness, tolerance towards rival conceptions and respect for rational arguments. In Kohlberg's view, someone who is just is capable of reasoning in accordance with moral principles, in particular with the principles of justice. This form of moral reasoning relates not only to individual actions but also to rules and laws (e.g. Kohlberg, 1971, p. 59). It is 
obvious that such an assessment of actions, rules and laws will generally be an exacting and complicated activity. In order to conclude such intricate thinking activities appropriately, we need intellectual virtues. For practising these virtues will increase the chance that our opinionforming practices (including our moral evaluation of actions, rules and laws) result in beliefs that are true or well-justified ( $c f$. Steutel and Spiecker, 1997).

Kohlberg expects the bearer of the virtue of justice to be capable of reasoning adequately about issues of justice. If we value such a competence, I argued, we will also have to attach value to a variety of intellectual virtues. However, the bearer of the virtue of justice is also capable of acting in a certain way. Next to judging appropriately, such a person is able to adjust his doings and dealings to his moral judgements. And in the preceding section we have seen that bridging the gap between judgement and action requires will-power. In other words, that one and only virtue of justice, as explained by Kohlberg, turns out to enclose both intellectual virtues and the virtues of will-power. This is surely quite a bag of virtues! ${ }^{3}$ In Kohlberg's second phase that bag is even further filled. Then he also considers the teaching of moral content to be part of moral education. And within the just community approach this content is explained in terms of virtues, mainly traits of character that are constitutive of 'a love of the common life'.

On the basis of this analysis we have good reasons to conclude that the second definition does not differentiate any better than the first one. If according to our second definition even the early theory of Kohlberg is a virtue approach, we can assume that such an approach is definitely not representing an alternative or new development in research on moral education. Perhaps such a conclusion was only to be expected. In research on moral education the dispositions of the moral person are by definition in the centre of interest. After all, these dispositions constitute the aims of moral education. And is it not only natural to regard such dispositions as virtues, or at least as aspects of virtues?

\section{A THIRD DEFINITION: MORAL EDUCATION FOUNDED IN AN ETHICS OF VIRTUE}

Yet we still cannot rule out the possibility that the virtue approach is in some respects essentially different from the cognitive-developmental theory. To be sure, if we employ the criterion of thinking about virtues as such, Kohlberg's view can be regarded as a virtue approach as well. But it could be that some recent publications on moral education are dealing with the virtues in a new and different way. And perhaps we should introduce a third definition that only relates to this recent, alternative approach within the broader field of reflection on virtues and education.

Surely such a definition will have to be more restrictive. On the basis of this definition we should be able to distinguish that alternative approach from other approaches to moral education. And because the 
first two definitions failed to bring about this differentiation, we have to formulate a more specific one by adding some defining conditions. What would such a definition be?

If I am not mistaken a suitable candidate is a definition that links a virtue approach with a virtue ethics. To put it more precisely: according to this definition a conception of moral education is a virtue approach if, and only if, the traits of character that are regarded as educational aims are founded in an ethics of virtue. But what exactly is a virtue ethics? And what does it mean to found the aims of moral education in such an ethics?

It is well-known that in moral philosophy, in particular in AngloAmerican ethics, interest in virtues and vices has increased enormously during the last decades. In the past twenty years or so one could witness a growing stream of publications on the nature of virtues, on different types of virtues, on virtues and character, virtues and emotions, virtues and motives, as well as on the problem of the unity of the virtues and the relationship between virtues and human flourishing. However, systematic reflection on virtues is one thing, developing a virtue ethics is quite another thing. Contrary to many other philosophical accounts of virtues, an ethics of virtue is presented as a rival of or an alternative to the standard conceptions of ethics, in particular Kantianism, utilitarianism and moral intuitionism. For example, in his recent book Political Liberalism (1993) John Rawls discusses in various places the nature and function of political virtues like toleration, mutual respect, reasonableness, a sense of fairness and civility. Thus he contributes to the revival of thinking about virtues in moral philosophy. But because his account of the virtues is part of an ethical theory that has to be regarded as a variety of Kantianism, he is clearly not defending a virtue ethics. And the question is: what exactly is the difference between these well-known ethical theories like Kantianism and utilitarianism on the one hand, and an ethics of virtue on the other?

In relevant publications often two defining characteristics of a virtue ethics are mentioned ( $c f$. Frankena, 1970, pp. 6-11; 1973b, pp.63-65; 1973c; Brandt, 1981, pp. 271-273; Louden, 1984; Watson, 1990; Slote, 1992, pp. 88-93). A first criterion is that such an ethics takes aretaic concepts and judgements as basic or fundamental, at least in relation to deontic concepts and judgements. Examples of aretaic terms (from the Greek arete, 'excellence') are good and bad, courageous and cowardly, virtuous and vicious. Main examples of so-called deontic terms (from the Greek deon, often translated as duty) are right and wrong, duty and obligation, ought and must. As far as persons are concerned, the latter group of terms is only properly applicable to actions and practices, whereas instances of the former group also apply to intentions, motives, traits of character and to persons themselves. Moreover, as opposed to deontic terms, aretaic ones refer to scalar qualities, i.e. they are adjectives that have comparatives and superlatives. For example, to be good or admirable is to possess scalar 
qualities, since we can speak of the better and the best, the more admirable and the most admirable ( $c f$. Urmson, 1968, pp. 92-96).

Now, characteristic of an ethics of virtue is that aretaic concepts and judgements are treated as basic or primary, whereas deontic concepts and judgements either are considered unnecessary or inadequate, or are regarded as derived from or reducible to aretaic ones. An example of the first variant (deontic concepts are unnecessary or inadequate) has been defended by Elizabeth Anscombe. In her pioneering and controversial paper 'Modern moral philosophy' (1958), she repudiates all concepts of moral obligation and duty because she thinks that such concepts are not intelligible outside the framework of belief in divine law. According to her, we would do better to develop an Aristotelian kind of ethics, in which the only ethical concepts and judgments are aretaic ones. Michael Slote, however, has proposed an example of the second variant of an ethics of virtue (deontic concepts are derivative or reducible). He assigns a basic place to the aretaic pair of concepts admirable/deplorable, which is applied to actions as well as to motives, traits of character and individuals (Slote, 1992, pp.95-96). And in his view imperatives and 'ought' statements are derivable from aretaic assessments in which those twin concepts are used (pp. 159-167). ${ }^{4}$

A second feature that is often mentioned is that an ethics of virtue reduces aretaic judgements about actions to aretaic judgements about persons and their character. For example, a morally good deed is explained in terms of conduct that displays a moral virtue, or an action is regarded as noble if it is one that a noble or virtuous individual would perform. The idea is that when we judge actions in aretaic terms we always do so because of the motives, dispositions or traits of character they manifest. In short, according to the former criterion, an ethics of virtue is an aretaic ethics (and not a deontic one); and according to this second criterion, an ethics of virtue is a specific kind of aretaic ethics, namely, an aretaic agent ethics (and not an aretaic action ethics). ${ }^{5}$

Our third definition lays down that a virtue approach to moral education is founded in an ethics of virtue. That actually means that all aims of moral education are described with the help of aretaic statements, and that these statements either are part of the core of a virtue ethics or are derivative from such a basic core. In a virtue approach only traits of character are regarded as aims of education. As such these traits are typified in aretaic terms, namely as good or admirable qualities, or in short as virtues. And if these aretaic judgements are regarded as ethically basic, or as derived from such basic judgements, then moral education is founded in an ethics of virtue and a virtue approach is at issue.

According to this definition, the theory that I developed in my Deugden en morele opvoeding is clearly not a virtue approach. In that book I defended the view that moral virtues are composed of intrinsic wants and aversions that motivate the agent to act in accordance with moral rules or principles. Some morally good traits, which I called nonteleological virtues, only correspond to moral rules that lay down which 
kinds of action are morally right or morally required (so-called duties and obligations). This view is contrary to the first criterion of a virtue ethics: aretaic judgements (e.g. 'Fidelity is a non-teleological virtue') are derived from deontic judgements (e.g. 'One ought to keep one's promises'). Because it is our duty to perform or to refrain from certain kinds of action, certain wants or aversions concerning these actions are virtuous or are constitutive of a virtue. Other morally good traits, which I called teleological virtues, find their counterpart also and sometimes even exclusively in moral rules that lay down which kinds of action are morally desirable or recommendable (so-called principles of supererogation). Here I defend a view that does not meet the second criterion: aretaic judgements regarding traits of character (e.g. 'Helpfulness is a teleological virtue') are dependent on aretaic judgements about actions (e.g. 'Offering this kind of help is morally desirable'). Because performing or abstaining from certain conduct is morally recommendable, intrinsic wants and aversions towards this conduct are virtuous or central components of a virtue. In brief, in my book the aims of moral education are not founded in an ethics of virtue but in an ethics of principle. And because I thought it possible to justify those principles by impartially considering the interests of the members of a society, I defended a utilitarian version of an ethics of principle (Steutel, 1992, pp. 122-123).

But what of the theories of Kohlberg? Is his conception of moral education, given the third definition, perhaps a virtue approach? In my opinion the answer to this question must be negative. From the beginning Kohlberg has placed his approach in the centre of the Kantian or deontological tradition (e.g. Kohlberg, 1976, pp. 182-183). And within this tradition the fundamental core of ethics is regarded as composed of deontic concepts and judgements, or, in the words of Rawls, of 'the concept of right' and 'principles of the right'.

It has been already explained that Kohlberg considers the virtue of justice to be a (or the) central aim of moral education. Consequently, aretaic judgements about the moral person and his character loom large in his theory. But these judgements are clearly not primary or basic. The aretaic evaluation of character traits is dependent on deontic statements, in particular on principles of justice. According to Kohlberg, we have to appeal to such principles if we want to determine which conduct is morally right. And the complex disposition to observe those principles in judgement and action is labelled as the virtue of justice. To put it differently, Kohlberg explains the virtue of justice in terms of principles of justice. And so he does not found moral education in a virtue ethics but in an ethics of principles, in particular in an ethics of principle of a markedly deontological persuasion. ${ }^{6}$

Our third definition seems indeed to be drawing a distinction between a virtue approach and well-known other approaches to moral education. In any case certain approaches are excluded, including the theory of Kohlberg. But can we assume that the definition is also including recently developed conceptions of moral education? Classical ethical 
theories, in particular those of Aristotle and varieties of Epicureanism and Stoicism, are rightly considered examples of an ethics of virtue. For that reason the accounts of education that are part of those theories can be regarded as examples of a virtue approach. But is it possible to point also to present-day conceptions of moral education that are, according to the third definition, virtue approaches?

It is difficult to give a plain answer to this question, in particular because in most recent educational publications in which virtues and character are highlighted, meta-ethical reflections on the distinction between an ethics of duty and an ethics of virtue are totally absent. Nevertheless, I am inclined to answer the question in the affirmative.

To begin with, John White's (1990) theory of moral education could perhaps be regarded as a virtue approach, in the third sense of that word. This at least could be inferred from his criticism of 'law-based conceptions of morality' and his defence of an alternative that is grafted onto the classics. Paul Crittenden (1990) is a clearer example of a virtue approach. Though he does not explicitly refer to the criteria of a virtue ethics, he typifies his view on both morality and moral development as a broadly Aristotelian approach. However, the most clear and powerful example of a virtue approach to moral education is found, without doubt, in recent publications of David Carr. In various places (1991, p. 87; 1995; 1996a; 1996b) he contrasts a Kantian perspective on morality ('an ethics of obligation') with an Aristotelian account of moral life ('an ethics of virtue'). He situates his own theory on moral education firmly in the latter tradition. And his intention is, in his own words, to explore the possibilities of a 'virtue-theoretical basis for understanding the nature of moral life and education' (1996b, p. 353).

I admit that this characterisation of recently published views is limited and somewhat speculative. But if I am right, an approach can be indicated that is clearly different from the cognitive-developmental view, including the just community approach. Then a new development can be explicated that is based on a very old body of thought. ${ }^{7}$

Correspondence: Jan W. Steutel, Department of Education, Vrije Universiteit, Van der Boechorststraat 1, 1081 BT Amsterdam, The Netherlands.

\section{NOTES}

1. In an earlier paper (Steutel, 1988) I made a distinction between three forms of reflection on central educational concepts, which I called the descriptive, rescriptive and prescriptive approaches. Introducing and discussing definitions of the virtue approach is an example of rescriptive reflection on educational concepts: current concepts of a virtue approach are vague and blurry and therefore replaced by more precise and clearly distinct ones.

2. The Character Education Partnership (a recently formed American organisation which aims at promoting character education nationwide) defines character education as 'the deliberate effort by schools, families, and communities to help young people understand, care about, and act upon core ethical values' (Lickona, 1996, p.93). Since virtues can be explained in terms of understanding, caring about (or being committed to) and acting upon correlating values, this 
definition of character education corresponds to my second definition of a virtue approach. Consequently, according to the definition of the Character Education Partnership even implementing Kohlberg's early theory would be an example of character education.

3. The idea that Kohlberg's aim of moral education is internally related to a lot of virtues is anything but new. In an interesting paper Dwight Boyd (1989) argued convincingly that stage six in Kohlberg's theory is congruent with a whole flock of virtues. Much earlier Richard Peters came to the similar conclusion that a principled level of moral reasoning corresponds to "quite a formidable "bag of virtues"' (1981, p. 178). However, the way they argue in favour of an internal relationship between post-conventional thinking and virtues is different from mine.

4. Another example of an advocate of the first variant is Richard Taylor (1988). In a vehement argument he expresses the wish 'that we once and for all expunge from our thinking the ideas of moral right and wrong ... and turn instead to the ideas of virtue and happiness' (p. 55). Another example of the second variant has been developed by Richard Brandt (1981). He thinks that for a complete normative theory deontic ethical judgements are indispensable. In his view, however, deontic terms like 'moral duty' can be defined plausibly in terms of 'morally bad' (or 'vicious').

5. Slote (1992, pp. 89-90) is of the opinion that this second criterion is too rigid. According to this criterion, he argues, even the ethical theory of Aristotle would not be a virtue ethics, since for Aristotle the ethical status of actions is not entirely derivative from that of traits or persons (but see Watson, 1990, note 24). Therefore, he introduces a less restrictive second criterion: an ethics of virtue puts a greater emphasis on the ethical assessment of agents and traits than it puts on the evaluation of actions (pp.xiv, 89, 93). However, preferring Slote's dissenting criterion to the usual one will not invalidate my main line of reasoning.

6. Though Boyd reveals intrinsic relations between stage six and traits of character (see note 2), his view cannot be considered a virtue approach, in the third sense of the word. Boyd attaches value to certain traits (or regard them as virtues) because they 'facilitate' or are 'in the service of' stage six moral thinking $(1989$, pp. 98, 109). And because this form of thinking is explained in terms of certain moral principles, aretaic statements like 'justice is a virtue' are derived from deontic statements like 'one ought to respect the rights and autonomy of others'.

7. I am grateful to Dwight Boyd, Ben Spiecker and the other members of our VU discussion group for their critical comments and helpful suggestions.

\section{REFERENCES}

Anscombe, G. E. M. (1958), Modern moral philosophy, Philosophy, 33, pp. 1-19.

Atherton, J. M. (1988), Virtues in moral education: objections and replies, Educational Theory, 38, pp. 299-310.

Boyd, D. (1989), The character of moral development, in: L. P. Nucci (ed.) Moral Development and Character Education. A Dialogue (Berkeley, McCutchan Publishing Corporation).

Brandt, R. B. (1981), W. K. Frankena and ethics of virtue, The Monist, 64, pp. 271-292.

Carr, D. (1991), Educating the Virtues. An Essay on the Philosophical Psychology of Moral Development and Education (London, Routledge).

Carr, D. (1995), The primacy of virtues in ethical theory: Part I, Cogito, 9, pp. 238-244.

Carr, D. (1996a), The primacy of virtues in ethical theory: Part II, Cogito, 10, pp. 34-40.

Carr, D. (1996b), After Kohlberg: Some implications of an ethics of virtue for the theory of moral education and development, Studies in Philosophy and Education, 15, pp. 353-370.

Crittenden, P. (1990), Learning To Be Moral. Philosophical Thoughts about Moral Development (New Jersey, Humanities Press International).

Dent, N. J. H. (1984), The Moral Psychology of the Virtues (Cambridge, Cambridge University Press).

Frankena, W. K. (1970), Prichard and the ethics of virtue. Notes on a footnote, The Monist, 54, pp. 1-17.

Frankena, W. K. (1973a), The concept of education today, in: J. F. Doyle (ed.) Educational Judgments. Papers in the Philosophy of Education (London, Routledge \& Kegan Paul).

Frankena, W. K. (1973b), Ethics (Englewood Cliffs, Prentice-Hall).

Frankena, W. K. (1973c), The ethics of love conceived as an ethics of virtue, The Journal of Religious Ethics, 1, pp. 21-36. 
Kohlberg, L. (1970), Education for justice: a modern statement of the socratic view, in: L. Kohlberg (1981), Essays on Moral Development. Vol. I: The Philosophy of Moral Development. Moral Stages and the Idea of Justice (San Francisco, Harper \& Row).

Kohlberg, L. (1971), Stages of moral development as a basis for moral education, in: B. Munsey (ed.), Moral Development, Moral Education, and Kohlberg. Basic Issues in Philosophy, Psychology, Religion, and Education (Birmingham, Alabama, Religious Education Press).

Kohlberg, L. (1976), The cognitive-developmental approach to moral education, in: D. Purpel and K. Ryan (Eds.), Moral Education. . . It Comes With the Territory (Berkeley, Phi Delta Kappa).

Kohlberg, L. (1978), Revisions in the theory and practice of moral development, in: W. Damon (ed.), Moral Development (San Francisco, Jossey-Bass).

Lickona, T. (1996), Eleven principles of effective character education, Journal of Moral Education, 25, pp. 93-100.

Louden, R. B. (1984), On some vices of virtue ethics, American Philosophical Quarterly, 21, pp. 227236.

Nash, R. J. (1988), The revival of virtue in educational thinking: a postliberal appraisal, Educational Theory, 38, pp. 27-39.

Nucci, L. P. (1989) (ed.), Moral development and character education. A dialogue (Berkeley, McCutchan Publishing Corporation).

Peters, R. S. (1981), Moral Development and Moral Education (London, George Allen \& Unwin).

Power, C., Higgins, A. and Kohlberg, L. (1989), The habit of the common life: building character through democratic community schools, in: L. P. Nucci (ed.), Moral Development and Character Education (Berkeley, McCutchan Publishing Corporation).

Rawls, J. (1993), Political Liberalism (New York, Columbia University Press).

Slote, M. (1992), From Morality To Virtue (New York, Oxford University Press).

Steutel, J. W. (1988), Forms of reflection on central educational concepts, Journal of Philosophy of Education, 22, pp. 163-171.

Steutel, J. W. (1992), Deugden en morele opvoeding. Een wijsgerig-pedagogische studie (Moral Education and the Virtues. An Essay in Philosophy of Education) (Amsterdam, Boom).

Steutel, J. W. and Spiecker, B. (1997), Rational passions and intellectual virtues. A conceptual analysis, Studies in Philosophy and Education, 16, pp. 59-71.

Straughan, R. (1988), Can We Teach Children To Be Good? Basic Issues in Moral, Personal and Social Education (Milton Keynes, Open University Press).

Taylor, R. (1988), Ancient wisdom and modern folly, in: P. A. French, T. E. Uehling and H. K. Wettstein (eds.), Midwest Studies in Philosophy. Vol. XIII. Ethical Theory: Character and Virtue (Notre Dame, University of Notre Dame Press).

Urmson, J. O. (1968), The Emotive Theory of Ethics (London, Hutchinson University Library).

Watson, G. (1990), On the primacy of character, in: O. Flanagan and A. O. Rorty (eds.), Identity, Character, and Morality. Essays in Moral Psychology (Cambridge, Mass., MIT Press).

White, J. (1990), Education and the Good Life. Beyond the National Curriculum (London, Kogan Page). 